Osuchowska D. (2021). Should translation teaching be incorporated into 'regular' English classrooms? Current Trends in Translation Teaching and learning E, 7, 483 - 510. https://doi.org/10.51287/cttle202117

\title{
SHOULD TRANSLATION TEACHING BE INCORPORATED INTO 'REGULAR' ENGLISH CLASSROOMS?
}

Dorota Osuchowska

University of Rzeszów

\section{Abstract}

A survey conducted on four different groups of professionally active subjects from the Subcarpathian region, Poland, revealed that employees who work in multilingual settings are regularly entrusted with typical translation and/or interpreting tasks that arise in such settings. Simultaneously, as also evidenced from the answers they provided, none of the courses of English they attended have prepared them for acting in the role of, as they referred to themselves, 'substitute translators'. The major stress in these classrooms the eighty participants were part of was typically placed on preparing a learner for situations in which one needs to express oneself in L2 and not for situations in which one is required to translate or interpret. This has resulted in some of the participants' suggestion for a special form of language pedagogy that would take into account that translation outside the classroom seems to have become the norm in contemporary global economy. The study, which ends with a brief presentation of the subjects' ideas, may be of interest to educationalists in the field of Translation Studies whose 
Osuchowska D. (2021). Should translation teaching be incorporated into 'regular' English classrooms? Current Trends in Translation Teaching and learning E, 7, 483 - 510. https://doi.org/10.51287/cttle202117

expertise may be exploited for the purpose of helping experts in ELT design suitable teaching materials.

Keywords: teaching translation, English for Occupational Purposes, learners' needs, TEFL, syllabus design

\section{INTRODUCTION}

A steady influx into the Polish economy of foreign companies in which communicating in English is the norm brought about an increased interest in learning this language; the appearance on the Polish educational market of private language schools facilitated this. Today, almost 90 per cent of the entire student population in Poland is learning English at schools and scholarly enquiries into this issue (see e.g. Vulliamy \& Webb, 1996; Kasztalska, 2014) show that it has become the most widely spoken foreign language in our country.

Judging by what one is taught in a standard contemporary English-language classroom, an individual who is seeking employment in a multilingual company and who has attained proficiency in English should, without much difficulty, succeed in linguistic tasks their future employer will charge them with. Teachers of English such an individual has had have certainly put considerable effort into enabling them to develop the ability to understand and express themselves in L2, both orally and in writing. On the other hand, a growing interest in certified postgraduate programmes in translation/interpreting begs the question whether the English-language courses offered 
Osuchowska D. (2021). Should translation teaching be incorporated into 'regular' English classrooms? Current Trends in Translation Teaching and learning E, 7, 483 - 510. https://doi.org/10.51287/cttle202117

these days indeed prepare one for handling all situations in which the knowledge of a foreign language is called for. A survey administered to participants of three subsequent editions of such a programme suggests this is not the case and this has, in turn, made some of them postulate that the teaching of translation as a skill in its own right could, perhaps, be integrated into standard English classes, a proposal which I discuss against the backdrop of current research on the place of translation in the foreign language class. As the results of this discussion clearly indicate, it is uncertain at the moment if such a proposal will ever be given serious consideration, as experts in teaching foreign languages seem to be focusing on whether translation, understood as an activity learners of foreign languages continually engage in does or does not support the acquisition of a new language. As a matter of fact, only a few suggest that no harm would be done if ordinary learners would occasionally be given translation exercises imitative of those assigned to students who have decided to take translation up as a career.

\section{METHODOLOGY}

When the survey I briefly mention above was administered for the first time, its results were primarily aimed at providing a picture of former experiences in interpreting (if any) students were coming with to the interpreting class. The class itself was part of a year-long post-graduate weekend programme in translation set up in 2016 by a local university. Informal exchanges with 
Osuchowska D. (2021). Should translation teaching be incorporated into 'regular' English classrooms? Current Trends in Translation Teaching and learning E, 7, 483 - 510. https://doi.org/10.51287/cttle202117

students who enrolled on the programme revealed that all of them were professionally active individuals working in various sectors of the economy across the region; the wish to polish translation skills was motivated not so much by a desire to enter a new career path as in connection with tasks they were regularly charged with in an occupational context.

Having learned that the main purpose behind the survey was to eventually adjust the contents of the interpreting course in such a way that it included tasks that would make sense from their point of view, most of the students who were enrolled in the first edition of the programme took the time to complete it. ${ }^{1}$ This yielded the total of 16 surveys collected in 2016. A decision to repeat the survey with students who enrolled in the second and third edition of the programme resulted in the collection of a further 34 surveys, and this, put together, amounts to 50 complete surveys filled out by this particular group.

The second group of students among whom the survey was distributed consisted of individuals enrolled on a Master's programme offered by the same university. Technically speaking, the programme these students chose ends with a specialization in teaching English as a foreign language. On the other hand, since many Polish language majors

\footnotetext{
${ }^{1}$ As in the case of other studies conducted by the present author, also this survey was administered after securing permission from the university and subjects were informed that filling it out implies their consent.
} 
Osuchowska D. (2021). Should translation teaching be incorporated into 'regular' English classrooms? Current Trends in Translation Teaching and learning E, 7, 483 - 510. https://doi.org/10.51287/cttle202117

eventually decide to follow a different career path (Hargreaves, 2009), disillusioned with low salaries or other disadvantages of the teaching profession, their teaching curriculum also includes some classes in translation/interpreting presented as one of the career options (see also Zimányi, 2017) people who speak foreign languages can follow after leaving university. The administration of the survey to this second group brought about an increase in the total number of those collected between 2016 and 2019 to 80 .

Since the primary rationale behind the administration of the survey was, each time, to learn what type of interpreting tasks students would benefit from the most, its questions revolved primarily around previous experiences in interpreting/translating (if any). Each of the groups was instructed to distinguish between translation/interpreting tasks entrusted by their present and past employers and those one is set outside one's place of work. Since, as I assumed, my subjects could also be asked for help with tasks entrusted to their family members, friends or anyone they knew, a distinct question asking about such experiences has also been provided.

The on-the-job interpreting/translation tasks had to be characterized in terms of the texts subjects were expected to handle, the usual modes in which they were expected to operate, directionality (i.e. whether translations were carried out from their L1 to L2, in the opposite or in both directions) and who such tasks are typically allocated by. Finally, subjects were also asked about their perceptions 
Osuchowska D. (2021). Should translation teaching be incorporated into 'regular' English classrooms? Current Trends in Translation Teaching and learning E, 7, 483 - 510. https://doi.org/10.51287/cttle202117

concerning whether the language courses they had attended in the past prepared them for coping with these tasks and to justify their answers by talking about, e.g. the levels of (dis)comfort they were experiencing in such circumstances or problems they would not know how to solve.

Subjects who were attending the teacher training programme could also report experiences that only they could have: whether teachers of English are being prepared for an eventual presence in their classrooms of adults whose on-the-job duties also entail a requirement to translate. My own experience as a teacher of English suggests that translation outside the class has become the norm which is connected with the status of English as the lingua franca of international business, the media and so on. Due to the ubiquitous presence of English 'out there' one may expect that learners of English may want to discuss the 'correctness' of a 'funny' translation they may have spotted while watching a movie or while processing the contents of a hotel website which, as they assume, has not been translated the way it should have and teachers of English seem a natural choice for doing this. While asking about whether an average Polish teacher trainee is being prepared for the fact that translation will somehow be present in their classroom whether they want it or not, I meant primarily the teaching methodology books and

lectures that future teachers of English have as a mandatory component of their teaching curriculum. 
Osuchowska D. (2021). Should translation teaching be incorporated into 'regular' English classrooms? Current Trends in Translation Teaching and learning E, 7, 483 - 510. https://doi.org/10.51287/cttle202117

In order not to place inordinate demands on subjects' time, questions were formulated in such a way as to enable answering them with a simple "Yes" or "No". Additional space for a commentary, if someone would like to add one, was also provided. Questions were formulated in Polish, which is connected with the fact that - as my former research experience dictated - having a survey in a foreign language may result in misinterpretations. As it soon turned out, such a risk indeed existed, especially in the case of some subjects from the post-diploma group. As regards students from the teacher trainee group, their English turned out to be more fluent, but this could not be predicted in advance.

Finally, to avoid a situation in which the subjects might have doubts about a question's scope, in-built instructions or glosses, to be capitalized upon in cases of doubt, have been provided. To exemplify, terms such as consecutive interpreting were appended with a brief explanation about what happens when one performs in this particular mode. Whenever necessary, these in-built instructions also specified whether the question pertained to interpreting or to translating. A category 'Other' allowed for adding one's own examples to those the question was prompting on.

\section{RESULTS}


Osuchowska D. (2021). Should translation teaching be incorporated into 'regular' English classrooms? Current Trends in Translation Teaching and learning E, 7, 483 - 510. https://doi.org/10.51287/cttle202117

Even though work-unrelated translation was also the norm $(\mathrm{N}=80)$, the general consensus of the answers received was that Polish employees who know English are regularly entrusted with such translation $(\mathrm{N}=80)$ and interpreting $(\mathrm{N}=80)$ tasks that are typical of occupational settings in which business is partly conducted in this language. An identical tendency was reported in this part of Question One in which subjects from both groups were supposed to talk about the experiences of their family members $(\mathrm{N}=16$; $\mathrm{NP}-\mathrm{D}=12 ; \mathrm{NTT}=4),{ }^{2}$ friends $(\mathrm{N}=12 ; \mathrm{NP}-\mathrm{D}=6$; $\mathrm{NTT}=6)$ or (in the case of the teacher trainee group) their (adult) students $(\mathrm{NTT}=6)$.

Electronic correspondence was the most frequent type of text $(\mathrm{N}=43$; $\mathrm{NP}-\mathrm{D}=23$; $\mathrm{NTT}=20$ ) subjects (or someone they knew) were supposed to handle. As one can conclude on the basis of commentaries provided by the subjects, not all e-mails an employee is asked to send are created de novo; very frequently one must translate a text that has been written by a co-worker or a superior. The incoming mail must also be translated for the benefit of those coworkers who do not speak English sufficiently well to handle correspondence on their own.

The next most frequent type of text subjects had to translate was the company's website which had originally

\footnotetext{
2 The abbreviations used stand for: $\mathrm{N}$ - the total number of responses to a question; NP-D - the number of responses in the post-diploma group; NTT - the number of students from the teacher trainee group who marked this answer.
} 
Osuchowska D. (2021). Should translation teaching be incorporated into 'regular' English classrooms? Current Trends in Translation Teaching and learning E, 7, 483 - 510. https://doi.org/10.51287/cttle202117

been written in Polish. Fourteen subjects $(\mathrm{N}=14$; NP-D=9; NTT=5) claimed they were asked to help translate the contents of the existing company's website into English and that this very task comprised texts of various length and complexity (which, as the commentaries revealed, stood for such texts' saturation with technical vocabulary). Translating newsletters placed next in frequency $(\mathrm{N}=12$; NP-D=10; NTT=2), followed by leaflets that had to be prepared for international fairs or exhibitions ( $\mathrm{N}=11$; NP$\mathrm{D}=9 ; \mathrm{NTT}=2)$, (written) presentations $(\mathrm{NP}-\mathrm{D}=7 ; \mathrm{NTT}=1)$ and technical texts $(\mathrm{NP}-\mathrm{D}=6)$. As far as the 'interpreting section' of this question is concerned, the most frequent interpreting task that the subjects reported consisted in rendering dialogues that took place during official business meetings (NP-D=46), followed by official speeches $(\mathrm{NP}-\mathrm{D}=7)$ and presentations $(\mathrm{NP}-\mathrm{D}=4)$ made during such meetings.

Requests to translate/interpret were usually made by a superior $(\mathrm{N}=67$; NP-D=65; NTT=2) - a finding which is consistent with how Mooney et al. (2013) describe the ability to speak English in the older generation of Poles who, incidentally, also own a substantial number of private companies in Poland. Translating/interpreting following a request by a peer in the company's hierarchy turned out to be less common $(\mathrm{NP}-\mathrm{D}=13)$, which is consistent with research referred to in the introduction which points to a growing ability on the part of subsequent generations of Poles to communicate in English. 
Osuchowska D. (2021). Should translation teaching be incorporated into 'regular' English classrooms? Current Trends in Translation Teaching and learning E, 7, 483 - 510. https://doi.org/10.51287/cttle202117

Nineteen respondents, 17 from the post-diploma and 2 from the teacher trainee group reported that they often took the texts to be translated home. Doing such texts 'on the go', e.g. a business trip, so as to work on them while on a train or aboard a plane was reported by an additional three subjects, all from the post-diploma group. 15 postdiploma students claimed that the translations of texts they had to work on had to be completed on the company's premises due to confidentiality clauses that do not allow taking some of the documentation out. With respect to interpreting, consecutive interpreting as a mode in which one had to perform was marked by the greatest number of subjects (NP-D=46), with whispered interpreting pointed to by four subjects only (NP-D=4). An in-between between written and oral translation, sight translation, was reported by twenty-three subjects from the post-diploma group. The most remarkable development in connection with this particular item was the appearance of commentaries $(\mathrm{NP}-\mathrm{D}=25)$ that talked about how "the circumstances make one discover the 'right' mode". As these commentaries explained, when one is, all of a sudden, told to interpret, procedural decisions on how to proceed must be taken on the spot and there is no time to ponder about whether this is how a professional translator would approach such a task.

As far as directionality is concerned, translating/interpreting from Polish to English turned out to be the most frequently requested direction subjects pointed to $(\mathrm{N}=37$; NP-D=30; NTT=7). This particular finding indicates that, firstly, the reality out there may be 
Osuchowska D. (2021). Should translation teaching be incorporated into 'regular' English classrooms? Current Trends in Translation Teaching and learning E, 7, 483 - 510. https://doi.org/10.51287/cttle202117

much harsher than what one normally would be experiencing in many specialized translation programmes in which students may initially be asked to do what is considered the easier option: translating into their L1. Secondly, this higher demand for translating into L2 may be caused by the fact that speaking English is still a source of considerable discomfort for many Poles who will go to considerable lengths to find a substitute so as not to have to do it on their own. Such an effect can also be observed in informal settings (e.g. on holidays), with a lot of fingerpointing at those who should take upon themselves the task of communicating something, as their English is apparently 'so much better' than the English of the rest of the group. This hypothesis is also corroborated when one considers that translating in both directions came second $(\mathrm{N}=24 ; \mathrm{NP}-\mathrm{D}=23$; $\mathrm{NTT}=1)$, the smallest demand being for translating/interpreting only from English to Polish $(\mathrm{N}=19 ; \mathrm{NP}-\mathrm{D}=12 ; \mathrm{NTT}=7)$.

Finally, the majority of subjects felt that previous tuition in English they had received was of little help as far as their ability to succeed in the tasks they were supposed to perform was concerned $(\mathrm{N}=76$; $\mathrm{NP}-\mathrm{D}=46$; $\mathrm{NTT}=30)$. As subjects argued in the commentaries, this type of tuition one normally receives in an English-language classroom does not automatically translate into translational competence $(\mathrm{NP}-\mathrm{D}=16 ; \mathrm{NTT}=6)$. If teaching a foreign language and this type of training that translation professionals must undergo were one and the same thing, there would be no long-term training programmes people who want to take translation up as a career have to enroll 
Osuchowska D. (2021). Should translation teaching be incorporated into 'regular' English classrooms? Current Trends in Translation Teaching and learning E, 7, 483 - 510. https://doi.org/10.51287/cttle202117

on (NP-D=9; NTT=12). Neither the (English) classes one attends in state schools nor courses of English offered in the private language sector prepare one for acting in the capacity of, as one of the subjects put it, "in-house substitute translators" (NP-D=7; NTT=4) which she glossed as "employees who must do what a 'real translator' (if there was one on staff) would normally be doing". (Paid) private tutorials which have always been popular in Poland also do not teach one (NP-D=7) how to behave when one is ordered to translate - at best these private tutors may kindly agree to take a look at a translation their student was asked to prepare and "correct the mistakes that had crept in" $(\mathrm{NP}-\mathrm{D}=2)$.

Further justification provided under this question on how well or how poorly the English classes subjects attended prepared them for doing the translation tasks that became part and parcel of their daily routine consisted in listing the difficulties they experienced while translating/interpreting. Fourteen subjects (NP-D=13; NTT=1) speculated that translation professionals are "probably never lost for the 'right' translation equivalent". Two subjects from the post-diploma group added that "if they initially are, the one they ultimately decide for is probably not the 'second best' one chosen for lack of a word that should have been used". By the same token, professionals probably know whether one is "allowed to alter what has been said or even omit it entirely" (NP$\mathrm{D}=7$ ). Finally, professional interpreters they had a chance "to watch in action never asked the speaker for more 
Osuchowska D. (2021). Should translation teaching be incorporated into 'regular' English classrooms? Current Trends in Translation Teaching and learning E, 7, 483 - 510. https://doi.org/10.51287/cttle202117

frequent pauses" (NP-D=12) or to "repeat the contents of what they said only a few sentences ago" $(\mathrm{NP}-\mathrm{D}=8){ }^{3}$

Thirteen subjects from the last edition of the post-diploma programme opined that foreign language classes, especially those offered at higher levels, should be more translation-oriented. The issue came up again during informal exchanges we had towards the end of the programme and I discuss it at greater length in the 'Discussion' section underneath, where the suggestion is evaluated against the backdrop of those developments in foreign language teaching that indicate whether or not educationalists are likely to give it serious consideration.

Finally, as can be assumed on the basis of answers provided by subjects from the teacher trainee group, the teaching methodology classes they had to attend did not prepare them for the fact that some of their students may be expecting some guidance on how to cope with the translation tasks they are being entrusted with. The teaching methodology books they were asked to read depict translational competence as the highest form of linguistic competence one can aspire at achieving and suggest that developing the skills that define such a competence can only be done in specialized training

\footnotetext{
${ }^{3}$ It is not certain what observations subjects who raised this issue were relying on - one may hypothesize that "in action" entailed professionals observed live or professionals they had had a chance to observe on television, e.g. during state visits with broadcasts frequently showing an interpreter at work.
} 
Osuchowska D. (2021). Should translation teaching be incorporated into 'regular' English classrooms? Current Trends in Translation Teaching and learning E, 7, 483 - 510. https://doi.org/10.51287/cttle202117

programmes addressed at individuals who want to take translation up as a career $(\mathrm{NTT}=10)$. Regarding what constitutes the ultimate goal of FLT as depicted in such books, learners must end up with the ability to communicate in a foreign language $(\mathrm{NTT}=8)$ and this communicative competence is best developed with the help of reading, listening, speaking and writing and not translation activities (NTT=6). Translation, especially exercises in which students would be applying grammatical rules and words a teacher had presented to them would amount to teaching about language and not teaching to communicate in this language (NTT=15). Even though the sources on the basis of which these claims were being made were not identified, familiarity with books currently in use with Polish teachers-to-be allow the assumption that they were drawing on either Pfeiffer (2001) or Harmer (2007) or both.

\section{DISCUSSION AND CONCLUSION}

The survey met the primary practical goal set to it, as thanks to it in-class/home assignments such as preparing a glossary of terms or specific interpreting tasks students would be carrying out in class could take into account the needs of each specific group. Unarguably, it also enhanced our present knowledge concerning the identification of the needs of adults who at one point were learning a foreign language and who next have to apply what they learnt outside a language class. 
Osuchowska D. (2021). Should translation teaching be incorporated into 'regular' English classrooms? Current Trends in Translation Teaching and learning E, 7, 483 - 510. https://doi.org/10.51287/cttle202117

Importantly, too, the survey provided the subjects with an opportunity to reflect upon their specific situation. Regarding the subjects from the last edition of the postdiploma programme, it gave them an opportunity to further reflect on an idea some of them presented while answering one of the survey's questions, when they opined that foreign language classes, especially those offered to more advanced learners of English should be more translation-oriented.

The reasons that the P-D subjects gave while elaborating on this idea during the informal exchanges we engaged in towards the end of their course mostly had to do with how well (or how poorly) the current educational offer serves their specific needs. As they argued, these needs are not adequately met by specialized university programmes, addressed at and attended by individuals who are planning to take translation/interpreting up as a career. Someone who, like them, already has a profession and is not interested in career change will not invest in a new training programme whose curriculum offers much more than people like them need. The same pertains to training materials available online, as their abundance makes it very difficult for interested parties to see which of the resources actually lend themselves for use in their particular case and which actually feature the sought after characteristics, e.g. the answer to a question that prompted the search.

Regarding the programme they eventually enrolled on, a comparison of its aims and contents with the 'educate 
Osuchowska D. (2021). Should translation teaching be incorporated into 'regular' English classrooms? Current Trends in Translation Teaching and learning E, 7, 483 - 510. https://doi.org/10.51287/cttle202117

oneself' and the specialized training options initially suggested that it may be the softest among all three. However, as it turned out as soon as the programme started, it contained more than, as some felt, they really needed to learn. This, in turn, lead to the conclusion that the survival minimum that they could probably safely get by at work could be easily delivered within ordinary English language courses and not necessarily an extra programme, participation in which inadvertently meant investments in terms of both time and money.

When I asked these students how precisely an ordinary language class could become more translation-oriented, two alternative ideas were forwarded. The first consisted in having practice exercises in translation built into subsequent units of course books addressed at students who needed English at work. As they reasoned, since the books they were taught from do have a certain number of activities (e.g. writing a business letter) that may prove of use at work, it should not be a problem to append such English-only activities with extras - additional exercises in the course of which students could practice translating the contents of a Polish business letter into English. During such exercises teachers could provide students with basic guidance on what to avoid - precisely this type of guidance that they were hoping to get after enrolling on their post-diploma programme.

The second idea subjects put forward consisted in designing an independent translation component that could be placed at, say, the end of the regular course book. 
Osuchowska D. (2021). Should translation teaching be incorporated into 'regular' English classrooms? Current Trends in Translation Teaching and learning E, 7, 483 - 510. https://doi.org/10.51287/cttle202117

Subsequent units of such a component would teach one what to do and what to avoid, such mini-lessons in translation/interpreting illustrated with examples of a text followed with a 'good' and a 'bad' translation. Students could also be given an opportunity to do a number of carefully selected and graded translation exercises that would basically be imitative of those used in 'real' translation classes. A consensus was reached that the preparation of such a component should be entrusted to experienced translators/interpreters, as only they would be in the position to determine if preparing such a survival minimum is possible at all and, if so, what specific elements it should consist of.

As clearly evidenced by what the subjects said, while formulating these two proposals previous and current work experience was drawn upon to some extent. To exemplify, a student who currently worked in marketing added that appending some English course books with a translation component would certainly increase their market value. By the same token, the necessity to grade the exercises was pointed at by a student who for many years worked as a teacher of Russian. As this individual also stressed, had such an idea indeed been implemented, in whatever form, teachers of English would have absolute discretion over whether to use such a translation component with a given group. Finally, as argued by the same individual, since course books available these days are always offered in a package, such a complete package comprising of, among other elements, a teacher's book, would offer the possibility of providing an 'ordinary' 
Osuchowska D. (2021). Should translation teaching be incorporated into 'regular' English classrooms? Current Trends in Translation Teaching and learning E, 7, 483 - 510. https://doi.org/10.51287/cttle202117

English language teacher with detailed instructions on how to do the activities they normally have no experience with.

The fundamental question that arises in connection with the ideas and suggestions P-D students forwarded is as follows: will syllabus designers ever give serious consideration to having the best of the two worlds combined within a single course? If we provided the students with a short recap of developments in the history of language teaching, they would discover that translation exercises did, for a long time, constitute an integral part of all those settings in which foreign languages were taught. On the other hand, it would not take them long to notice that it is not the same translation exercises as those they had in mind. An identical conclusion would be reached if we provided them with a listing of older and more recent studies that show learners the world over continue to translate irrespective of whether their teachers want them to or not, ${ }^{4}$ work in which this tendency on the part of the students is viewed as something natural to be taken advantage of as well as work which argues to the contrary (for an overview see e.g. Cook, 2010). While the review of all this literature clearly evidences that the teaching

${ }^{4}$ Such as: Heltai (1989); Kern (1994); Husain (1995); Prince (1996); Cohen and Brooks-Carson (2001); Carreres (2006); Liao (2006); Källkvist (2008); Wilhelm and Chen (2008); Brooks-Lewis (2009); Bagheri and Fazel (2011); Calis and Dikilitas (2012); Karimian and Talebinejad (2013); Al-Musavi (2014); Fernandez-Guerra (2014); Kim and Yoon (2014); Tavakoli et al. (2014); Asgarian and Vefali (2015); Mutlu et al. (2015); Ying et al. (2018). 
Osuchowska D. (2021). Should translation teaching be incorporated into 'regular' English classrooms? Current Trends in Translation Teaching and learning E, 7, 483 - 510. https://doi.org/10.51287/cttle202117

world is still divided on the issue of having translation within a foreign language class, it simultaneously contains no indication that ELT experts are considering turning an English language class into a translation class, if only occasionally.

In fact, the only source I came across that contains such a proposal, Malmkjaer (2010), suggests that learners of foreign languages might benefit from what she calls "properly situated translation exercises" (p. 187). "Situated", as one may hypothesize, means that such exercises would simulate typical situations in which clients 'out there' commission translations. The brief description of these exercises the scholar provides us with gives grounds for calling them double-duty exercises as listening to (or reading) the instructions on what the 'client' expects the 'translator' to do would create the opportunity for practicing those very communicative skills that ELT experts believe are crucial in developing linguistic competence, while the very nature of an assignment would give a language learner a foretaste of what to expect if they decide to take up this popular career path.

As regards the remaining developments within ELT that may be taken as indicative of change being in the air, the first one that comes to mind is unarguably intense research "into the nature of learners' needs (needs analysis)" carried out within the English for Specific Purposes movement that culminated in the preparation of such teaching materials that would best "meet those needs" 
Osuchowska D. (2021). Should translation teaching be incorporated into 'regular' English classrooms? Current Trends in Translation Teaching and learning E, 7, 483 - 510. https://doi.org/10.51287/cttle202117

(Dudley-Evans, 1991, p. 459). Reasoning by analogy, we can assume that should future research confirm that this ability to translate/interpret is what a significant number of learners of English are going to need one day, syllabi designers may want to somehow acknowledge this fact and develop courses in which the basics of translating are laid out.

A similar conclusion can, in my view, be reached with respect to the continuing popularity, since the 1980s, of the Eclectic Approach. One of the lessons that can be drawn with respect to this particular development is that teaching methodologies are in a state of constant flux, with those that have been in disrepute for years reappearing again and even though most of the elements reinstated to the class originated in syllabi devised within the field, there is in theory no reason why such borrowings should not become more interdisciplinary in nature. So far each of the parties, experts in ELT and experts in Translation Studies keep to what is for both of them familiar ground, but one may well imagine that the expertise the latter gained since the emergence of Translation Studies as an academic discipline can one day be exploited for the purpose of helping the former design such materials my students were talking about. The ongoing presence in some FL textbooks of the very same exercises that were in use within the Grammar-Translation syllabi (Munday, 2008, p. 8) points in the same direction, as if they are still in use, space can also be created for Malmkjær's "properly situated translation tasks" treated as a "more effective means of teaching [a certain aspect] of a foreign language" 
Osuchowska D. (2021). Should translation teaching be incorporated into 'regular' English classrooms? Current Trends in Translation Teaching and learning E, 7, 483 - 510. https://doi.org/10.51287/cttle202117

(ibid., p. 188) as well as preparing the students for situations in which - as evidence presented above unarguably established - they may need to mediate between those who are not in a position to communicate and not solely to express themselves in L2.

The last development that may, in my opinion, result in introducing translation as a skill in its own right to an FL class is a relatively easy availability of teachers who are native speakers of various foreign languages. Even if such a teacher is not available locally, developments in technology should, one day, enable one to have lessons with a native speaker online at a relatively low cost. This may, in turn, lead to the re-examining of the role of local teachers and their ability to mediate between the two language systems may, one day, start being utilized for the purpose of, among other things, preparing a student for handling such translation tasks that, as again evidenced above - are becoming the norm. Even though the creation of programmes such as the one described above can be regarded as a positive development, we saw that some professionally active students may reject such an idea on the grounds that what they need to know could be taught in less time and such students should not be lost sight of, the only resources at their disposal when they need to translate being common sense, intuition - and a mobile phone.

\section{REFERENCES}


Osuchowska D. (2021). Should translation teaching be incorporated into 'regular' English classrooms? Current Trends in Translation Teaching and learning E, 7, 483 - 510. https://doi.org/10.51287/cttle202117

Al-Musawi, N. M. (2014). Strategic use of translation in Learning English as a Foreign Language (EFL) among Bahrain University Students. Comprehensive Psychology, 3(4), 1-10. https://doi.org/10.2466/10.03.IT.3.4

Asgarian, A., \& Vefalı, G. M. (2015). How do English translation majors use translation strategies? A survey of the Iranian EFL context. Journal of Multilingual and Multicultural Development, 36(3), 313-329.

https://doi.org/10.1111/j.1540-4781.2011.01275.x

Bagheri, M. S., \& Fazel, I. (2011). EFL learners beliefs about translation and its use as a strategy in writing. Reading Matrix: An International Online Journal, 11(3), 292-301.

Brooks-Lewis, K. A. (2009). Adult learners' perceptions of the incorporation of their L1 in foreign language teaching and learning. Applied Linguistics, 30(2), 216-235.

\section{https://doi.org/10.1093/applin/amn051}

Calis, E., \& Dikilitas, K. (2012). The use of translation in EFL classes as L2 learning practice. Procedia Social and Behavioral Sciences, 46, 5079-5084. https://doi.org/10.1016/j.sbspro.2012.06.389

Carreres, A. (2006). Strange bedfellows: Translation and language teaching, the teaching of translation into 
Osuchowska D. (2021). Should translation teaching be incorporated into 'regular' English classrooms? Current Trends in Translation Teaching and learning E, 7, 483 - 510. https://doi.org/10.51287/cttle202117

L2 in modern languages degree; uses and limitations. Sixth Symposium on Translation, Terminology and Interpretation in Cuba and Canada, December 2006 (pp. 1-21). Cambridge University Press.

http://www.cttic.org/publications_06Symposium. $\underline{\operatorname{asp}}$

Cohen, A. D., \& Brooks-Carson, A. (2001). Research on direct versus translated writing: Students' strategies and their results. The Modern Language Journal, 85(2), 169-188. https://doi.org/10.1111/0026-7902.00103

Cook, G. (2010). Translation in language teaching: An argument for reassessment. Oxford University Press.

https://doi.org/10.1111/j.1473-4192.2010.00259.x

Dudley-Evans, T. (1991). Teaching English as a Foreign Language (TEFL). In K. Malmkjær \& J. M. Anderson (Eds.), The linguistics encyclopedia (pp. 457-461). Routledge.

Fernandez-Guerra, A. (2014). The usefulness of translation in foreign language learning: Student's attitudes. International Journal of English Language \& Translation, 2(1), 153-170. http://www.eltsjournal.org 
Osuchowska D. (2021). Should translation teaching be incorporated into 'regular' English classrooms? Current Trends in Translation Teaching and learning E, 7, 483 - 510. https://doi.org/10.51287/cttle202117

Hargreaves, L. (2009). The status and prestige of teachers and teaching. In L. J. Saha \& A. G. Dworkin (Eds.), International handbook of research on teachers and teaching (pp. 217-229). Springer. https://doi.org/10.1007/978-0-387-73317-3_13

Harmer, J. (2007). How to teach English. Pearson Education.

https://doi.org/10.1093/elt/ccn029

Heltai, P. (1989). Teaching vocabulary by oral translation. English Language Teaching Journal, 43(4), 288293.

http://dx.doi.org/10.1093/elt/43.4.288

Husain, K. (1995). Assessing the role of translation as a learning strategy in ESL. International Journal of Translation, 1(2), 59-84.

Karimian, Z., \& Talebinejad, M. R. (2013). Students' use of translation as a learning strategy in EFL classroom. Journal of Language Teaching and Research, 4(3), 605-610. https://dx.doi.org/10.4304/j1tr.4.3.605-610

Kasztalska, A. 2014. English in contemporary Poland. World Englishes, 33(2), 242-262. https://doi.org/10.1111/weng.12083

Källkvist, M. (2008). L1-L2 translation versus no translation: A longitudinal study of focus- on-form 
Osuchowska D. (2021). Should translation teaching be incorporated into 'regular' English classrooms? Current Trends in Translation Teaching and learning E, 7, 483 - 510. https://doi.org/10.51287/cttle202117

within a meaning-focused curriculum. In L. Ortega \& H. Byrnes (Eds.), The Longitudinal Study of Advanced L2 Capacities (pp. 182-202). Routledge.

Kern, R. (1994). The role of mental translation in second language reading. Studies in Second Language Acquisition, 16, 441-461. https://doi.org/10.1017/S0272263100013450

Kim, Y., \& Yoon, H. (2014). The use of L1 as a writing strategy in L2 writing tasks. GEMA Online ${ }^{\circledR}$ Journal of Language Studies, 14(3), 33-50. http://dx.doi.org/10.17576/GEMA-2014-1403-03

Liao, P. (2006). EFL learners' beliefs about and strategy use of translation in English learning. Regional Language Centre Journal, 37(2), 191-215. https://doi.org/10.1177\%2F0033688206067428

Malmkjær, K. (2010). Language learning and translation. In Y. Gambier \& L. van Doorslaer (Eds.), Handbook of translation studies (pp. 185-190). John Benjamins.

Mooney, A., Brannen, J., Wigfall, V., \& Parutis, V. (2013). The impact of employment on fatherhood across family generations in white British, Polish and Irish origin families. Community, Work \& Family, 16(4), 372-389. http://dx.doi.org/10.1080/13668803.2012.746575 
Osuchowska D. (2021). Should translation teaching be incorporated into 'regular' English classrooms? Current Trends in Translation Teaching and learning E, 7, 483 - 510. https://doi.org/10.51287/cttle202117

Munday, J. (2008). Introducing translation studies: Theories and applications. Routledge.

Mutlu, G., Bayram, D., \& Demirbüken, B. (2015). Translation as a learning strategy of Turkish EFL learners. International Journal on New Trends in Education and Their Implications, 6(2), 236-245.

Pfeiffer, W. (2001). Nauka języków obcych: Od praktyki do praktyki. Wydawnictwo WAGROS.

Prince, P. (1996). Second language vocabulary learning: The role of context versus translation as a function of proficiency. The Modern Language Journal, 80, 478-493.

https://doi.org/10.1111/j.1540$\underline{\text { 4781.1996.tb05468.x }}$

Tavakoli, M., Ghadiri, M., \& Zabihi, R. (2014). Direct versus translated writing: the effect of translation on learners' second language writing ability. GEMA Online® Journal of Language Studies, 14(2), 61-74. http://dx.doi.org/10.17576/GEMA-2014-1402-05

Vulliamy, G., \& Webb, R. (1996). Education during political transition in Poland. International Journal of Educational Development, 16(2), 111123.

https://doi.org/10.1016/0738-0593(95)00001-1 
Osuchowska D. (2021). Should translation teaching be incorporated into 'regular' English classrooms? Current Trends in Translation Teaching and learning E, 7, 483 - 510. https://doi.org/10.51287/cttle202117

Wilhelm, K. H., \& Chen Pei, B. (2008). University teachers and students' perceptions of ELT methodologies and their effectiveness. GEMA Online $^{\mathrm{TM}}$ Journal of Language Studies, 8(2), 79102.

Ying, B. T., Hoon, A. L., Halim, H. A., \& Majtanova, M. (2018). Students' beliefs on translation strategy in learning German language. GEMA Online ${ }^{\circledR}$ Journal of Language Studies, 18(1), 69-86. http://dx.doi.org/10.17576/gema-2018-1801-05

Zimányi, K. (2017). Student perceptions of an elective introductory translation course on teacher training degrees at a public university in Central Mexico. Current Trends in Translation Teaching and Learning E, 4, 152-197. 